(c) American Dairy Science Association, 2004.

\title{
Use of Estradiol Cypionate as a Substitute for GnRH in Protocols for Synchronizing Ovulation in Dairy Cattle*
}

\author{
J. S. Stevenson, ${ }^{1}$ S. M. Tiffany, ${ }^{2}$ and M. C. Lucy ${ }^{3}$ \\ ${ }^{1}$ Department of Animal Sciences and Industry, \\ Kansas State University, Manhattan 66506-0201 \\ ${ }^{2}$ Department of Animal Sciences, \\ University of Missouri, Columbia 65211
}

\begin{abstract}
Our purpose was to determine whether estradiol cypionate (ECP) could be substituted for the second GnRH injection of the standard Ovsynch protocol (injection of GnRH given $7 \mathrm{~d}$ before and $48 \mathrm{~h}$ after $\mathrm{PGF}_{2 \alpha}$, with timed AI [TAI] 12 to $20 \mathrm{~h}$ after the second $\mathrm{GnRH}$ injection). Lactating dairy cows ranging from 61 to $82 \mathrm{~d}$ in milk at TAI were studied in 14 replicates. Main effects were hormone (ECP vs. GnRH) to induce ovulation and exposure to progesterone (P4) or not during the week preceding $\mathrm{PGF}_{2 \alpha}$-induced luteolysis. Four treatments were: 1) $100 \mu \mathrm{g}$ of $\mathrm{GnRH}$ at $48 \mathrm{~h}$ after $\mathrm{PGF}_{2 \alpha}$ (Ovsynch; $\mathrm{n}=27$ ); 2) same as Ovsynch, plus a P4-releasing intravaginal insert (CIDR) placed for $7 \mathrm{~d}$ beginning at the first $\mathrm{GnRH}$ injection (Ovsynch + CIDR, $\mathrm{n}=20$ ); 3 ) same as Ovsynch, but substituting $1 \mathrm{mg}$ of ECP for $\mathrm{GnRH}$, and injecting $\mathrm{ECP}$ at $24 \mathrm{~h}$ after $\mathrm{PGF}_{2 \alpha}$ (Heatsynch; $\mathrm{n}=33$ ); or 4 ) Heatsynch + CIDR $(\mathrm{n}=26)$. The largest follicle was identified by ultrasonography $24 \mathrm{~h}$ after $\mathrm{PGF}_{2 \alpha}$ and was monitored every $6 \mathrm{~h}$ until ovulation. Incidence of estrus was less after GnRH (54\%) than after ECP (87\%), but more GnRH-treated cows had LH surges detected (95 vs. $65 \%$ ) and ovulated (100 vs. $86 \%$ ). Duration of $\mathrm{LH}$ surges, but not peak concentrations, was less after GnRH than after ECP $(6.1 \pm 0.7$ vs. $12.2 \pm 0.9$ h). Pretreatment with $\mathrm{P} 4$ reduced the incidence of $\mathrm{LH}$ surges but had no effects on incidence of estrus or ovulation. Intervals to the LH surge and ovulation were less after GnRH than after ECP, but intervals between onset of the LH surge and ovulation did not differ (26 \pm 2 vs. $30 \pm 3 \mathrm{~h}$ ). We concluded that substituting ECP for GnRH resulted in more cows in estrus and slightly fewer ovulating.
\end{abstract}

(Key words: estrogens, progesterone, GnRH, ovulation)

Received February 23, 2004.

Accepted May 5, 2004.

Corresponding author: J. S. Stevenson; e-mail: jss@ksu.edu.

*Contribution Number 04-292-J, from the Kansas Agricultural Experiment Station, Manhattan.
Abbreviation key: CIDR = controlled internal drugreleasing intravaginal insert containing progesterone; $\mathbf{C L}=$ corpus luteum; $\mathbf{E C P}=$ estradiol cypionate, Heatsynch = injection of GnRH $7 \mathrm{~d}$ before an injection of $\mathrm{PGF}_{2 \alpha}$, followed in $24 \mathrm{~h}$ by $1 \mathrm{mg}$ of ECP and one fixedtime AI 42 to $50 \mathrm{~h}$ after ECP; Heatsynch + CIDR = same as Heatsynch plus a CIDR insert for $7 \mathrm{~d}$ at the time of first GnRH injection; Ovsynch = injection of GnRH $7 \mathrm{~d}$ before and $48 \mathrm{~h}$ after an injection of $\mathrm{PGF}_{2 \alpha}$, with one timed $\mathrm{AI}$ at 16 to $22 \mathrm{~h}$ after the second $\mathrm{GnRH}$ injection; Ovsynch + CIDR = same as Ovsynch plus a CIDR insert for $7 \mathrm{~d}$ at the time of first GnRH injection; $\mathbf{P 4}=$ progesterone; $\mathbf{T A I}=$ timed $\mathrm{AI}$.

\section{INTRODUCTION}

Programmed breeding makes it feasible to schedule AI of dairy cattle during the first week that follows the end of the volunteer waiting period. The Ovsynch protocol (Pursley et al., 1995) synchronizes ovulation before timed artificial insemination (TAI) with pregnancy rates in the range of 30 to $40 \%$ (Burke et al., 1996; Pursley et al., 1997; Stevenson et al., 1999). Further work in Florida (Moreira et al., 2001) and in Kansas (Cartmill et al., 2001; El-Zarkouny et al., 2004) demonstrated that presynchronizing estrous cycles of cows to $\mathrm{d} 5$ to 12 of the estrous cycle (Vasconcelos et al., 1999) by either 1 or 2 injections of $\mathrm{PGF}_{2 \alpha}$ preceding the initiation of the Ovsynch protocol, significantly improved pregnancy rates, by 24 to $48 \%$ beyond what was achieved with Ovsynch alone.

Use of the Ovsynch protocol produces few cows in estrus because the peak in estrogen secreted by the preovulatory follicle is prematurely abrogated by the LH surge that is induced by the second GnRH injection after $\mathrm{PGF}_{2 \alpha}$-induced luteal regression. Uterine tone and presence of mucus, which are traditional validations that cows are truly in estrus, often are limited or absent at TAI. Cervical penetration and semen placement with the breeding catheter may be more difficult when cows have not been exposed to normal estrogen concentrations secreted by mature preovulatory follicles. As few 
as $20 \%$ of Ovsynch-treated cows show estrus after the $\mathrm{PGF}_{2 \alpha}$ injection associated with the Ovsynch protocol (Stevenson et al., 1996).

Substituting estrogen for the second GnRH injection is a logical choice for numerous reasons, including cost and the induction of normal estrual characteristics such as mucous secretion, uterine tone, and resulting sexual behavior. This progression of events more logically simulates a natural estrus when estrogen is given at the proper time after $\mathrm{PGF}_{2 \alpha}$-induced luteal regression. The only estrogen product available in the United States was estradiol cypionate (ECP), which has multiple label indications, including one "to correct anestrus [absence of heat period] in the absence of follicular cysts" at large doses of 3 to $5 \mathrm{mg}$. Esterification of estradiol$17 \beta$ to produce ECP increases the half-life of the estrogen, with release of the parent estradiol following hydrolysis (Vynckier et al., 1990). Studies using a large dose (10 $\mathrm{mg}$ ) of ECP resulted in a peak in plasma estradiol at $20 \mathrm{~h}$ that remained elevated for as long as $5 \mathrm{~d}$ (Vynckier et al., 1990). Administration of $2 \mathrm{mg}$ of ECP was sufficient to cause ovariectomized heifers to display estrus (Lefebvre and Block, 1992).

Further, estradiol benzoate has been used to induce estrus and ovulation in lactating dairy cattle (Dailey et al., 1986). Estrogen potentiates the LH surge via actions on hypothalamic GnRH and the resulting $\mathrm{LH}$ surge during proestrus (Hansel and Convey, 1983) and enhances the release of $\mathrm{GnRH}$ in response to exogenous GnRH in the ovariectomized cow (Britt et al., 1981). Substituting ECP for GnRH in an Ovsynch-like protocol (known as Heatsynch) induced estrus, preovulatory LH surge, ovulation, and normal corpus luteum (CL) development in dairy heifers (Lopes et al., 2000), and induced estrus and ovulation in lactating dairy cows (Pancarci et al., 2002). Conception rates of ECP-treated heifers were not different from those in heifers inseminated after detected estrus (Lopes et al., 2000) and those in lactating cows after Heatsynch were similar to those after Ovsynch (Pancarci et al., 2002).

The current experiment was conducted to examine timing and variation of events critical to establishing conception (onset of estrus, LH surge, and ovulation) as useful references for future efforts to refine control of estrus and ovulation. Specifically, our objectives were to determine the incidences and characteristics of estrus, preovulatory LH surge, and ovulation in lactating dairy cattle after use of ECP as a substitute for GnRH in an ovulation synchronization protocol preceding a timed insemination.

\section{MATERIALS AND METHODS}

\section{Experimental Design}

Lactating Holstein cows $(n=119)$ were housed in either covered free stalls bedded with sand or in a tie-

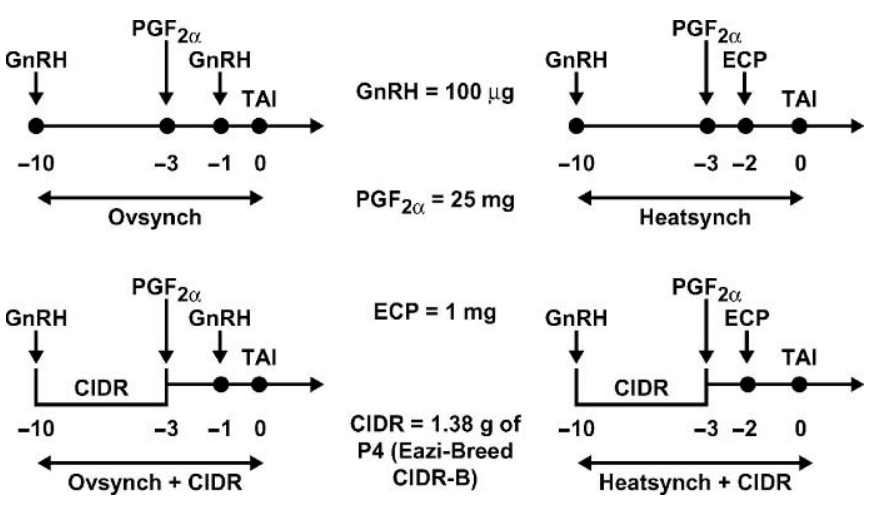

Figure 1. Experimental design illustrating 4 treatments in which ovulation was synchronized before timed $\mathrm{AI}(\mathrm{TAI})$. Blood was collected on $\mathrm{d}-10,-3$, and -1 to determine concentrations of progesterone. In 3 replicates, blood was also collected at $0,1,2,3,4,5,6,8$, and 10 $\mathrm{h}$ after $\mathrm{GnRH}$ (expected $\mathrm{LH}$ peak at $2 \mathrm{~h}$ after $\mathrm{GnRH}$ ) or at 24,25 , $26,27,28,29,30 \mathrm{~h}$, then at 2 -h intervals until $58 \mathrm{~h}$ after estradiol cypionate (ECP) (expected LH peak at $44 \mathrm{~h}$ after ECP) to determine incidence, timing, duration, and onset of the induced LH surge. Transrectal ultrasonography to determine incidence and timing of ovulation occurred at 6 -h intervals starting $48 \mathrm{~h}$ after $\mathrm{PGF}_{2 \alpha}$. Onset of estrus was determined electronically by using HeatWatch in some replicates, but all cows were inseminated at one fixed time (TAI). CIDR $=$ controlled internal drug-releasing intravaginal insert containing progesterone, $\mathrm{P} 4$ = progesterone.

stall barn during all or part of the current study conducted at the Kansas State University Dairy Teaching and Research Center. The herd consists of approximately 200 cows, with an annual rolling herd average of $10,400 \mathrm{~kg}$ of milk (milked $2 \times$ daily). All cows were fed to meet or exceed NRC (1989) recommendations for lactating cows. A total mixed diet consisting of chopped alfalfa, corn silage, whole cottonseed, and a concentrate-mineral mix was offered twice daily. Cows had ad libitum access to fresh water.

Fourteen breeding clusters of lactating dairy cows, ranging from 61 to $82 \mathrm{DIM}$ at TAI were studied between September 2000 and May 2001. Cows were blocked by lactation number ( 1 vs. $2+$ ) and assigned to a $2 \times 2$ factorial arrangement of 4 treatments. All cows were administered $100 \mu \mathrm{g}$ of GnRH (Cystorelin, Merial, Iselin, $\mathrm{NJ}$ ), followed in $7 \mathrm{~d}$ by $25 \mathrm{mg}$ of $\mathrm{PGF}_{2 \alpha}$ (Lutalyse, Pharmacia Animal Health, Kalamazoo, MI). Main effects were hormone (ECP vs. GnRH) to induce ovulation and exposure to progesterone (P4) or not during the week preceding $\mathrm{PGF}_{2 \alpha}$-induced luteolysis. Therefore, 4 treatments were designed for cows to receive (Figure 1): 1) $100 \mu \mathrm{g}$ of $\mathrm{GnRH}$ at $48 \mathrm{~h}$ after $\mathrm{PGF}_{2 \alpha}$ (Ovsynch; $\mathrm{n}=27$ ); 2) as Ovsynch plus a P4-releasing intravaginal insert (controlled internal drug release, or CIDR, containing $1.38 \mathrm{~g}$ of $\mathrm{P} 4$; InterAg, Hamilton, NZ) placed for $7 \mathrm{~d}$ beginning at the first GnRH injection (Ovsynch + CIDR, $\mathrm{n}=20$ ); 3) same as Ovsynch, but substituting $1 \mathrm{mg}$ of ECP (ECP, Pharmacia Animal Health), for 
GnRH, and injecting ECP at $24 \mathrm{~h}$ after $\mathrm{PGF}_{2 \alpha}$ (Heatsynch; $\mathrm{n}=33)$; or 4$)$ Heatsynch + CIDR $(\mathrm{n}=26)$. Actual insemination times were 65 to $74 \mathrm{~h}$ after $\mathrm{PGF}_{2 \alpha}$ (corresponding to 16 to $22 \mathrm{~h}$ after $\mathrm{GnRH}$ or 42 to $50 \mathrm{~h}$ after ECP). The rationale for using the CIDR inserts was to: 1) synchronize more closely proestrous events that were studied; and 2) determine any effects of P4 on the timing of estrus, ovulation, and endocrine events studied.

Not every measurement could be assessed in each cow studied because of the necessity to have cows housed in either tie stalls or free stalls to accommodate blood collection or normal sexual behavior. Numbers of clusters and cows used for study were: timing of ovulation (11 clusters and 105 cows); timing of estrual events (4 clusters and 34 cows); timing of the preovulatory LH surge (3 clusters and 42 cows); and visual detection for occurrence of estrus during the breeding week for cows housed in outside free stalls (10 clusters and 85 cows).

\section{Blood Collection}

Blood samples were collected from all cows before administering the first or only GnRH injection, before $\mathrm{PGF}_{2 \alpha}$, and $24 \mathrm{~h}$ after $\mathrm{PGF}_{2 \alpha}$ for later determination of concentrations of $\mathrm{P} 4$. These samples were used to determine cycling status of cows and incidence of luteolysis after $\mathrm{PGF}_{2 \alpha}$. Progesterone was measured in blood sera by radioimmunoassay (Skaggs et al., 1986). Interand intraassay CV of 3 assays were 9.6 and $7.9 \%$, respectively.

In 3 replicates, blood was collected from cows housed in tie stalls at $0,1,2,3,4,5,6,8$, and $10 \mathrm{~h}$ after $\mathrm{GnRH}$ (expected $\mathrm{LH}$ peak at $2 \mathrm{~h}$ after $\mathrm{GnRH}$ ) and at 24, 25, $26,27,28,29,30,32$, and $34 \mathrm{~h}$, then at 2 -h intervals until $58 \mathrm{~h}$ after ECP (expected LH peak at $44 \mathrm{~h}$ after ECP; Lopes et al., 2000) to determine incidence, timing, duration, and onset of the induced LH surge.

Serum LH concentrations were measured by a validated radioimmunoassay. Serum $(200 \mu \mathrm{L})$ was incubated with $200 \mu \mathrm{L}$ of anti-oLH (TEA \#35; J. J. Reeves, Washington State University, Pullman) diluted $1: 50,000$ in assay buffer $(0.1 \%$ gelatin, $0.01 \%$ thimerosal, $0.01 M \mathrm{PO}_{4}, 0.9 \% \mathrm{NaCl}, \mathrm{pH}$ 7.2, with normal rabbit serum [1:300] and $0.01 M$ EDTA) at $4^{\circ} \mathrm{C}$ for $24 \mathrm{~h}$. On $\mathrm{d} 2,100 \mu \mathrm{L}$ of assay buffer containing approximately $20,000 \mathrm{cpm}\left[{ }^{125} \mathrm{I}\right]-\mathrm{oLH}$ (LER 1374a; gift from L. E. Reichert, Albany Medical College, NY) were added, and the incubation continued for an additional $24 \mathrm{~h}$ at $4^{\circ} \mathrm{C}$. Precipitation of antibody complexes began on $\mathrm{d} 3$ with the addition of $100 \mu \mathrm{L}$ of goat anti-rabbit antiserum (1:50 dilution in assay buffer). On d $6,3 \mathrm{~mL}$ of PBS was added to each tube, and tubes were centrifuged at $3000 \times g$ for $30 \mathrm{~min}$ at $4^{\circ} \mathrm{C}$. Supernatant was decanted, and the pellet was counted for $1 \mathrm{~min}$. Concentrations of LH in unknown samples were estimated from a standard curve $(0.02,0.04,0.08,0.16,0.31,0.63,1.25,2.50$, 5.0 , and $10 \mathrm{ng} / \mathrm{tube}$ ) using bLH (USDA-bLH-B6). Increasing volumes of bovine plasma $(50,100$, and 200 $\mu \mathrm{L})$ resulted in a displacement curve that was parallel to the standard curve. The addition of different masses of bLH to the assay $(0.25,0.5$, and $1.0 \mathrm{ng} /$ tube $)$ resulted in an average recovery of $101 \%$. Intra- and interassay CV were 8 and $12 \%$, respectively.

\section{Ovarian Ultrasonography}

Ovarian structures were monitored in 11 replicates of cows by using transrectal ultrasonography (real time, B-Mode, linear array, diagnostic, ultrasound scanner equipped with a $5-\mathrm{MHz}$ transducer, Aloka $500 \mathrm{~V}$, Wallingford, CT). Diameter of the largest ovarian follicle identified 24 and $72 \mathrm{~h}$ after $\mathrm{PGF}_{2 \alpha}$ was measured by using electronic calipers (average of vertical and horizontal measures) and then monitored at 6-h intervals until it disappeared (ovulation) or until $102 \mathrm{~h}$ after $\mathrm{PGF}_{2 \alpha}$. Ovaries of cows in most replicates were reexamined by ultrasonography to validate ovulation and location of the CL on d 13 after TAI. Pregnancy was diagnosed 30 to $32 \mathrm{~d}$ after TAI by using ultrasonography (presence of uterine fluid and conceptus).

\section{Estrous Behavior}

In 4 replicates of cows housed in free stalls, HeatWatch devices (DDx, Inc., Denver, CO) were affixed to cows to monitor characteristics of estrus (duration, number of standing events, and total duration of standing time per estrus), and intervals from $\mathrm{PGF}_{2 \alpha}$ to estrus and ovulation. Estrual activity was monitored electronically, during and after treatments, until pregnancy diagnosis. Cows having at least 2 or more standing events, for at least $2 \mathrm{~s}$ each were defined to be in estrus; otherwise, those HeatWatch data were counted as falsepositive events.

\section{Statistical Analyses}

Characteristics of estrus (incidence [all cows, including those fitted with detection devices] and traits associated with estrus [duration, number of standing events, and total standing time]) were analyzed by ANOVA (general linear models procedure; SAS Inst. Inc., Cary, NC) according to the following model: hormone (ECP vs. GnRH), CIDR (CIDR vs. no CIDR), lactation number (1 vs. $2+$ ), all 2 -way interactions among the previous independent variables, and season (fall, winter, and spring). 
All characteristics of ovulation (incidence and intervals between $\mathrm{PGF}_{2 \alpha}$, ECP, and GnRH and ovulation) were analyzed as just described according to a similar model. Characteristics of the LH surge (incidence, duration, and peak) and intervals from $\mathrm{PGF}_{2 \alpha}, \mathrm{ECP}$, and $\mathrm{GnRH}$ to onset of the LH surge were analyzed as just described without the season effect (these studies were conducted during a 35-d period). In instances for which limited numbers of observations were available for analyses (hours to estrus after $\mathrm{PGF}_{2 \alpha}, \mathrm{ECP}$, and $\mathrm{GnRH}$ ) and hours from estrus to ovulation, a reduced model was employed that excluded 2 -way interactions of the main effects with lactation number. To determine differences in diameter of the largest preovulatory follicle (measured $24 \mathrm{~h}$ after $\mathrm{PGF}_{2 \alpha}$ ), the model only included CIDR, lactation number, their interaction, and season because this measurement occurred before administration of either ECP or GnRH after $\mathrm{PGF}_{2 \alpha}$-induced luteolysis. In fewer numbers of cows, the putative ovulatory follicle was measured $72 \mathrm{~h}$ after $\mathrm{PGF}_{2 \alpha}$, and the effect of $\mathrm{GnRH}$ or ECP and their interaction with CIDR was added to the previous model.

In all models, treatment differences were determined by resulting $F$-tests in the ANOVA, whereas all other differences were determined by using the least-significant difference test (PDIFF option in SAS plus the Tukey adjustment) when protected by a significant $(P \leq$ $0.05) F$-test in the ANOVA.

\section{RESULTS}

\section{Characteristics of Estrus}

Estrus was detected in 34 of $44(77.3 \%)$ cows. A greater $(P<0.05)$ proportion of cows were detected in estrus (also includes visually detected estrus in cows without electronic devices) after ECP than after GnRH during the week that followed the injection of $\mathrm{PGF}_{2 \alpha}$ (87\% vs. 54\%). Only 4 Ovsynch cows (2 with and 2 without previous $\mathrm{P} 4$ exposure) equipped with electronic estrus-detection devices were detected in estrus. The addition of the P4 via the CIDR insert had no effect on the incidence of estrus. Duration of estrus among Heatsynch cows tended $(P=0.08)$ to be greater in those previously treated with $\mathrm{P} 4$ via the CIDR insert (7.4 \pm $1.3 \mathrm{~h}[\mathrm{n}=10])$ than in those not given $\mathrm{P} 4(4.4 \pm 1 \mathrm{~h}$ $[\mathrm{n}=13])$. The number of standing events per female in estrus ( $31 \pm 11$ vs. $11 \pm 13)$ and total standing time (7.4 \pm 6 vs. $13.5 \pm 5$ s) did not differ between Heatsynch cows treated with P4 and those without CIDR inserts, respectively.

Intervals from $\mathrm{PGF}_{2 \alpha}$ to onset of estrus were only numerically less $(P=0.11)$ in Heatsynch cows after previous exposure to $\mathrm{P} 4(46 \pm 7 \mathrm{~h})$ than in those not given $\mathrm{P} 4(60 \pm 5 \mathrm{~h})$. Heatsynch cows treated with $\mathrm{P} 4$ tended $(P=0.06)$ to have shorter intervals to estrus after ECP $(19 \pm 5 \mathrm{~h})$ than did herdmates not given P4 $(33 \pm 4 \mathrm{~h})$.

\section{Follicle Diameters}

Diameter of the ovulatory follicle $24 \mathrm{~h}$ after $\mathrm{PGF}_{2 \alpha}$ was greater $(P<0.01)$ in cows previously treated with P4 (14.6 \pm 0.4 vs. $13.1 \pm 0.4 \mathrm{~mm})$. The difference tended to be greater, however, in first lactation $(15.2 \pm 0.8$ [ $\mathrm{n}=$ $14]$ vs. $12.5 \pm 0.7 \mathrm{~mm}[\mathrm{n}=17])$ than in multiple-lactation cows $(14.0 \pm 0.5[\mathrm{n}=29]$ vs. $13.6 \pm 0.5 \mathrm{~mm}[\mathrm{n}=41]$; CIDR $\times$ lactation number interaction; $P=0.06$ ). By 72 $\mathrm{h}$ after $\mathrm{PGF}_{2 \alpha}(24 \mathrm{~h}$ after $\mathrm{GnRH}$ and $48 \mathrm{~h}$ after ECP), no differences in diameter of the ovulatory follicle were detected.

\section{Characteristics of Ovulation and Induced LH Surges}

Mean responses and ranges in values for each characteristic are summarized for 42 cows studied to determine the onset of the preovulatory LH surge (Table 1). Proportionally more $(P<0.05) \mathrm{LH}$ surges were detected during the sampling period in Ovsynch than in Heatsynch cows (95 vs. 65\%). In contrast, among cows treated with a CIDR insert, fewer $(P<0.05) \mathrm{LH}$ surges were detected (68 vs. $90 \%$ ), particularly among Heatsynch cows previously treated with $\mathrm{P} 4$.

As expected, onset of the LH surge occurred earlier $(P<0.001)$ after administration of GnRH than of ECP ( $1 \pm 2$ vs. $35 \pm 2$ h). Among Heatsynch cows, however, onset occurred much sooner in those previously treated with $\mathrm{P} 4$ (CIDR $\times$ hormone interaction; $P<0.05$ ). Average LH response curves among GnRH-treated cows treated with $\mathrm{P} 4$ were superimposable upon those of GnRH-treated cows not exposed previously with P4. Duration of the LH surge was greater $(P<0.001)$ after ECP than after GnRH $(12.2 \pm 0.9$ vs. $6.1 \pm 0.7 \mathrm{~h})$, but the maximum concentration (peak) associated with the LH surge did not differ among treatments.

Intervals from ECP to ovulation were greater $(P<$ 0.001 ) than those from GnRH to ovulation ( $59 \pm 2$ vs. $26 \pm 2 \mathrm{~h}$ ). But intervals from onset of the LH surge to ovulation were consistent among hormones and did not differ, whether induced by GnRH or ECP (26 \pm 2 vs. 30 $\pm 2 \mathrm{~h}$ ). Exposure of cows to P4 did not influence timing of ovulation after either hormone (GnRH vs. ECP) or influence onset of the induced LH surge (Table 1).

Incidences of ovulation among cows in which we attempted to detect the LH surge tended $(P=0.09)$ to be greater in Ovsynch than Heatsynch cows, with previous treatment with $\mathrm{P} 4$ having no effect (Table 1). Some discrepancy in the number of cows in each category in Table 1 is explained by the summary of outcomes listed 
Table 1. Timing and characteristics of preovulatory LH surges induced by either GnRH or estradiol cypionate (ECP) after Ovsynch or Heatsynch with or without previous exposure to progesterone via a progesterone-releasing intravaginal (CIDR) insert. ${ }^{1}$

\begin{tabular}{|c|c|c|c|c|c|c|c|}
\hline Item & \multicolumn{2}{|c|}{ GnRH (Ovsynch) } & \multicolumn{2}{|c|}{ ECP (Heatsynch) } & \multicolumn{3}{|c|}{$P$-values } \\
\hline Incidence of LH surge, ${ }^{2} \%$ & $100(9)$ & 90 (10) & 82 (11) & $50(12)$ & 0.03 & 0.04 & 0.31 \\
\hline Duration of LH surge, $\mathrm{h}$ & $\begin{array}{l}7 \pm 1 \text { (9) } \\
4-11^{3}\end{array}$ & $\begin{array}{l}6 \pm 1 \text { (9) } \\
3-7\end{array}$ & $\begin{array}{c}11 \pm 1 \text { (9) } \\
6-20\end{array}$ & $\begin{array}{l}13 \pm 1 \text { (6) } \\
11-15\end{array}$ & 0.001 & 0.85 & 0.26 \\
\hline Peak magnitude of LH surge, $\mathrm{ng} / \mathrm{mL}$ & $\begin{array}{l}4.8 \pm 1.2 \\
1-16^{3}\end{array}$ & $\begin{array}{l}4.7 \pm 1.2(9) \\
2-12\end{array}$ & $\begin{array}{l}3.3 \pm 1.1 \text { (9) } \\
2-5\end{array}$ & $\begin{array}{l}3.9 \pm 1.6 \\
1-7\end{array}$ & 0.38 & 0.84 & 0.75 \\
\hline Time from GnRH or ECP to ovulation, $h$ & $\begin{array}{l}28 \pm 3(9) \\
19-32^{3}\end{array}$ & $\begin{array}{l}25 \pm 3(8) \\
20-31\end{array}$ & $\begin{array}{l}61 \pm 3(7) \\
37-76\end{array}$ & $\begin{array}{l}58 \pm 3(8) \\
43-73\end{array}$ & 0.001 & 0.33 & 0.98 \\
\hline Time from LH surge to ovulation, $\mathrm{h}$ & $\begin{array}{l}26 \pm 2(9) \\
18-32^{3}\end{array}$ & $\begin{array}{l}26 \pm 3 \quad(7) \\
19-31\end{array}$ & $\begin{array}{l}29 \pm 3 \quad(6) \\
11-36\end{array}$ & $\begin{array}{l}32 \pm 3 \quad(5) \\
28-36\end{array}$ & 0.12 & 0.57 & 0.52 \\
\hline
\end{tabular}

${ }^{1}$ Cows were administered GnRH $7 \mathrm{~d}$ before $\mathrm{PGF}_{2 \alpha}$. Ovsynch cows were administered GnRH $48 \mathrm{~h}$ after PGF 2, whereas Heatsynch cows were given ECP $24 \mathrm{~h}$ after $\mathrm{PGF}_{2 \alpha}$. Cows in both treatments either were exposed to progesterone via a CIDR insert (CIDR) for $7 \mathrm{~d}$ preceding $\mathrm{PGF}_{2 \alpha}$ or served as controls (no CIDR). A total of 42 cows were studied to determine these characteristics.

${ }^{2} \mathrm{LH}$ surges were not detected in 9 cows during respective sampling periods (additional details in footnotes below).

${ }^{3}$ Range in values.

${ }^{4}$ In 1 cow in which an LH surge was not detected, premature luteolysis occurred before CIDR removal and early ovulation occurred before GnRH was administered.

${ }^{5}$ In 2 cows in which an LH surge was not detected, 1 cow ovulated early ( $37 \mathrm{~h}$ after ECP) and the other cow did not ovulate during the observational period probably because of delayed luteolysis (serum P4 = 3.1 ng/mL $24 \mathrm{~h}$ after $\mathrm{PGF}_{2 \alpha}$ ).

${ }^{6}$ In 6 cows in which an LH surge was not detected, 3 cows ovulated early (43, 50, and $64 \mathrm{~h}$ after ECP), 1 cow did not ovulate during the observational period probably because of delayed luteolysis (serum P4 $=3.1 \mathrm{ng} / \mathrm{mL} 24 \mathrm{~h}$ after PGF $\mathrm{PG}_{2 \alpha}$ ), and 2 cows had either a CL or cyst detected $13 \mathrm{~d}$ after TAI.

below and in footnotes to Table 1. Concentrations of P4 on the day of $\mathrm{PGF}_{2 \alpha}$ and $24 \mathrm{~h}$ later, ovarian scans to detect ovulation beginning $48 \mathrm{~h}$ after $\mathrm{PGF}_{2 \alpha}$, and ovarian scans in most cows $13 \mathrm{~d}$ after TAI were used to account for these outcomes in each cow sampled. As indicated in Table 1, of all cows in which the LH surge was detected, only 1 cow failed to ovulate in the ECP + CIDR treatment. For at least 5 of the 6 cows that ovulated in which no LH surge was detected, the LH surge likely occurred before the blood sampling began ( 1 cow ovulated before $\mathrm{GnRH}$ and 4 cows ovulated after ECP during the early scanning period). The sixth cow had delayed luteolysis, and the LH surge likely occurred after the sampling period ended. Of the 2 cows in which neither ovulation nor the LH surge was detected, 1 had a CL on d 13 after TAI and likely ovulated late and the second failed to ovulate (a cystic structure was detected on $\mathrm{d} 13$ after TAI).

Of the 98 cows that ovulated during the study (regardless of whether they were sampled to detect the $\mathrm{LH}$ surge), $11.2 \%$ ovulated less than $48 \mathrm{~h}$ after $\mathrm{PGF}_{2 \alpha}$ (before the first ovarian scans that continued every 6 $\mathrm{h}$ ), and $7.1 \%$ ovulated more than $102 \mathrm{~h}$ after $\mathrm{PGF}_{2 \alpha}$ (based on ovarian scans made on d 13 after TAI). As expected, concentrations of $\mathrm{P} 4$ at the time of $\mathrm{PGF}_{2 \alpha}$ injection were less $(P<0.01)$ in those cows having early ovulation $(1.3 \pm 0.7 \mathrm{ng} / \mathrm{mL})$ than in cows that ovulated between 48 and $102 \mathrm{~h}$ after $\mathrm{PGF}_{2 \alpha}(4.0 \pm 0.3 \mathrm{ng} / \mathrm{mL})$ and those ovulating thereafter $(4.5 \pm 0.9 \mathrm{ng} / \mathrm{mL})$. Of the 8 cows that failed to ovulate during the study, 6 cows had elevated $\mathrm{P} 4(>1 \mathrm{ng} / \mathrm{mL})$ at $24 \mathrm{~h}$ after $\mathrm{PGF}_{2 \alpha}$, although concentrations of $\mathrm{P} 4$ had declined in all 8 cows by $>50 \%$ by $24 \mathrm{~h}$ after $\mathrm{PGF}_{2 \alpha}$.

Of the various characteristics associated with ovulation (Table 2) among cows in which blood was not sampled to detect LH surges, none was influenced by previous exposure of $\mathrm{P} 4$. This was consistent with findings for cows in which we attempted to detect $\mathrm{LH}$ surges (Table 1). Frequency of ovulation was greater $(P<0.05)$ in cows treated with GnRH than in those treated with $\operatorname{ECP}(100$ vs. $86 \%)$. Intervals to ovulation after the onset of estrus were not different among Heatsynch cows, regardless of previous P4 exposure. Intervals from $\mathrm{PGF}_{2 \alpha}$ to ovulation were greater $(P<0.001)$ in ECPtreated than GnRH-treated cows ( $86 \pm 2$ vs. $77 \pm 3 \mathrm{~h}$ ).

Pregnancy rates after Heatsynch were $28.4 \%$ ( $\mathrm{n}=$ $67)$ and after Ovsynch were $27 \%(\mathrm{n}=52)$. Those after treatment with the CIDR were $30.6 \%(\mathrm{n}=72)$ and no CIDR were $21.4 \%(\mathrm{n}=47)$.

\section{DISCUSSION}

Although few cows generally are detected in estrus during the breeding week after the $\mathrm{PGF}_{2 \alpha}$ injection of the standard Ovsynch protocol (Stevenson et al., 1996), just more than $50 \%$ were detected in estrus in the cur- 
Table 2. Incidence of ovulation and intervals to ovulation after estrus or after injections of $\mathrm{PGF}_{2 \alpha}$, GnRH, and estradiol cypionate (ECP) in all cows not sampled to determine preovulatory LH surges. ${ }^{1}$

\begin{tabular}{|c|c|c|c|c|c|c|c|}
\hline Item & \multicolumn{2}{|c|}{ GnRH (Ovsynch) } & \multicolumn{2}{|c|}{ ECP (Heatsynch) } & \multicolumn{3}{|c|}{$P$-values } \\
\hline Incidence of ovulation, $\%$ & $100(18)$ & $100(11)$ & $91(22)$ & 79 (14) & 0.03 & 0.66 & 0.22 \\
\hline Time from GnRH or ECP to ovulation, $h$ & $\begin{array}{l}27 \pm 3 \\
15-35^{3}\end{array}$ & $\begin{array}{l}29 \pm 4 \text { (11) } \\
21-34\end{array}$ & $\begin{array}{l}64 \pm 3(20) \\
42-99\end{array}$ & $\begin{array}{l}61 \pm 4 \\
24-45\end{array}$ & 0.001 & 0.92 & 0.50 \\
\hline Time from $\mathrm{PGF}_{2 \alpha}$ to ovulation, $\mathrm{h}$ & $\begin{array}{l}76 \pm 2 \\
64-83^{3}\end{array}$ & $\begin{array}{l}74 \pm 3(11) \\
69-84\end{array}$ & $\begin{array}{l}88 \pm 2(20) \\
66-123\end{array}$ & $\begin{array}{l}84 \pm 3 \\
65-115\end{array}$ & 0.02 & 0.87 & 0.52 \\
\hline
\end{tabular}

\footnotetext{
${ }^{1}$ Cows were administered GnRH $7 \mathrm{~d}$ before $\mathrm{PGF}_{2 \alpha}$. Ovsynch cows were administered GnRH $48 \mathrm{~h}$ after PGF $\mathrm{P}_{2 \alpha}$, whereas Heatsynch cows were given ECP $24 \mathrm{~h}$ after $\mathrm{PGF}_{2 \alpha}$. Cows in both treatments either were exposed to progesterone via a CIDR insert (CIDR) for $7 \mathrm{~d}$ preceding $\mathrm{PGF}_{2 \alpha}$ or served as controls (no CIDR).

${ }^{2}$ No statistical comparisons were made between Ovsynch and Heatsynch cows for these traits because only 3 cows in the Ovsynch treatments were detected in estrus.

${ }^{3}$ Range in values.
}

rent study compared with $87 \%$ of the cows treated with ECP. Estrual activity after ECP was somewhat consistent with other reports in replacement dairy heifers (41\%; Lopes et al., 2000) and lactating dairy cows (76\%; Pancarci et al., 2002). Duration of estrus was not increased by ECP, but was greater in all cows previously treated with $\mathrm{P} 4$, consistent with studies in ovariectomized, lactating cows pretreated with $\mathrm{P} 4$ before injections of estrogen (Vailes et al., 1992). At the dose of ECP used (1 mg), intensity of estrus was not increased by ECP. All characteristics of estrus (number of standing events, total standing time, and duration of estrus) were consistent with a previous report (Pancarci et al., 2002) and were within normal ranges of cows treated with GnRH, which should not influence the intensity of these traits. Normality of estrus after ECP for cattle treated during proestrus also was consistent with previous reports in replacement dairy and beef heifers (Richardson et al., 2002), lactating dairy cows (El-Zarkouny and Stevenson, 2004), and lactating beef cattle (Stevenson et al., 2003).

Injections of GnRH were more effective in causing the preovulatory LH surge than those of ECP. Part of that difference may have occurred because of sampling times at which blood was collected. Release of LH after GnRH in cattle generally occurs within minutes of injection, regardless of stage of the estrous cycle, including the luteal phase (Chenault et al., 1990) or during proestrus (Lucy and Stevenson, 1986; Lopes et al., 2000). Timing of estrogen-induced LH release is more variable than that after $\mathrm{GnRH}$ and is subject to various other controlling factors, including presence of lactation, days postpartum, dose, and stage of the estrous cycle (Short et al., 1979; Stevenson et al., 1983; Lucy and Stevenson, 1986).

It is possible that our collection period was not entirely appropriate for all cows relative to hormonal mi- lieu and timing of luteolysis. In cows previously treated with $\mathrm{P} 4$, it is clear that proportions of $\mathrm{LH}$ surges detected were reduced compared with those not treated with P4. Despite fewer detected LH surges in ECPtreated cows, durations of their LH surges were about twice as long as those detected after $\mathrm{GnRH}$, suggesting that the LH surge mimics characteristics of the natural LH surge more closely in proestrous cows treated with estrogen (Chenault et al., 1975), which is consistent with observations in heifers (Lopes et al., 2000).

Detection of fewer LH surges after estrogen is reasonable because $\mathrm{GnRH}$, not estrogen, is the immediate releasing factor for pituitary LH secretion (Hansel and Convey, 1983). During proestrus, endogenous estradiol increases to induce a preovulatory surge of LH (Chenault et al., 1975; Stumpf et al., 1989). Various factors may preclude LH release in response to exogenous estrogen stimulation, including potential stressors such as feed-bunk lockup restraint, blood collection, and frequent movement of cows (Bolinger et al., 1997). Repeated administration of ACTH (every $12 \mathrm{~h}$ for $7 \mathrm{~d}$ starting on 15 of the estrous cycle) disrupted pulsatile patterns of LH in proestrous heifers on d 19 of the cycle, reduced estradiol secretion, and delayed the LH surge, and ovulation was late, if it occurred at all (Dobson et al., 2001). Repeated acute stress during proestrus failed to elevate 24-h patterns of blood corticosteroids, but blocked occurrence of the preovulatory LH surge in all heifers (Stoebel and Moberg, 1982). In contrast, estrogen-induced release of $\mathrm{LH}$ in anestrous ewes treated continually with either cortisol or dexamethasone was not disrupted or altered (Moberg et al., 1981).

Incidence of ovulation was greater after GnRH than after ECP in the present study, in which ovulation was monitored between 48 and $102 \mathrm{~h}$ after $\mathrm{PGF}_{2 \alpha}$. Equal frequencies of early $(<24 \mathrm{~h}$ after ECP or $<24 \mathrm{~h}$ after $\mathrm{GnRH}$ ) and late ( $>78 \mathrm{~h}$ after ECP or $>54 \mathrm{~h}$ after $\mathrm{GnRH})$ 
ovulation occurred independent of main effects. Intervals from ECP to estrus, to onset of the LH surge, and to ovulation were greater than those after $\mathrm{GnRH}$, but intervals from either hormone to the onset of those events were proportional. More importantly, interval from the LH surge to ovulation was about 26 to $32 \mathrm{~h}$ after either hormone. Intervals to ovulation are consistent with other studies in which intervals were monitored in cows subject to the Ovsynch protocol (28 to 30 $\mathrm{h}$ between GnRH and ovulation; Pursley et al., 1995) or in cows spontaneously coming to estrus or in response to $\mathrm{PGF}_{2 \alpha}$ (28 h between onset of estrus and ovulation; Dransfield et al., 1998). Intervals to ovulation after ECP in the current study (60 to $65 \mathrm{~h}$ ) corroborate results in replacement heifers (Lopes et al., 2000), in which ovulation occurred an average 60 to $62 \mathrm{~h}$ after ECP.

Because of the difficulty of determining onset of estrus and onset of the LH surge in the same cows, we could not determine whether those 2 events were concurrent. Although average intervals from estrus to ovulation were about $5 \mathrm{~h}$ less in GnRH-treated cows than average intervals from the onset of the $\mathrm{LH}$ surge to ovulation, those in ECP-treated cows were nearly simultaneous, at 31 to $34 \mathrm{~h}$ and 29 to $32 \mathrm{~h}$, respectively. It seems that estrus and onset of the LH surge are nearly simultaneous after ECP and are not too different from what occurs in untreated cows that spontaneously come to estrus (Chenault et al., 1975) or in those in which estrus is induced by $\mathrm{PGF}_{2 \alpha}$ (Chenault et al., 1976).

Field trials in Texas and Florida designed to compare pregnancy rates after the Ovsynch and Heatsynch protocols reported no differences in fertility (Pancarci et al., 2002). Our unpublished studies confirm the previous report. In a concurrent study to the one reported herein, in which cows in the same herd were diagnosed not pregnant and then assigned to either the Ovsynch or Heatsynch protocols (without CIDR inserts), pregnancy rates did not differ (64/219 or $29.2 \%$ vs. $63 / 229$ or $27.5 \%$; Stevenson and Tiffany, unpublished data). In another experiment (Blevins et al., 2002) conducted concurrently with the present report, in which 141 cows were assigned to the Heatsynch protocol for insemination at their first service, pregnancy rates averaged $40 \%$ when assessed at 30 to $35 \mathrm{~d}$ after TAI.

Substituting estrogen for the second GnRH injection in an Ovsynch protocol is a logical choice because of cost. Cost of an ovulatory dose of estrogen, where market available, is less than $10 \%$ of the cost of an ovulatory dose of GnRH (100 $\mu \mathrm{g})$. Unfortunately, since the present study was completed, ECP has been withdrawn from the U.S. market. Other positive benefits of an estrogen include induction of normal estrual characteristics, such as mucous secretion, uterine tone, and resulting sexual behavior. These traits are positive indicators of estrus for inseminators because these characteristics validate the likelihood that the cow is in estrus (Pancarci et al., 2002).

\section{CONCLUSIONS}

Substituting ECP for GnRH resulted in more cows in estrus after $\mathrm{PGF}_{2 \alpha}$ than cows treated with the standard Ovsynch protocol. Although we have somewhat limited information, no evidence exists to suggest that injection of ECP ( $1 \mathrm{mg})$ produced characteristics of estrus that were outside of normal physiological ranges. Of those cows monitored for incidence of ovulation, fewer ovulated after ECP than after GnRH. Pretreatment with P4 had no effects on the incidence of estrus or ovulation, but fewer cows had a detected LH surge. Intervals from estrus to ovulation and from onset of the LH surge to ovulation were similar after either GnRH or ECP, suggesting that onset of estrus and the LH surge are nearly concurrent events. Pregnancy rates to timed AI after ECP in the current trial and others are similar to those to timed AI after GnRH.

\section{ACKNOWLEDGMENTS}

We express appreciation to: Pharmacia Animal Health (Kalamazoo, MI) for donation of Lutalyse and ECP used in these studies; Merial (Iselin, NJ) for supplying the Cystorelin; InterAg (Hamilton, NZ) for donation of the CIDR inserts; L. E. Reichert, Albany Medical College, NY, for donation of oLH for iodination; J. J. Reeves, Washington State University for donation of LH antiserum; and Betty Hensley for assistance in conducting laboratory work.

\section{REFERENCES}

Blevins, C. A., J. J. Aberle, J. E. Shirley, B. A. Hensley, S. M. Tiffany, and J. S. Stevenson. 2002. Effect of milking frequency, estradiol cypionate, and bST on milk yield and reproductive outcomes in dairy cows. J. Dairy Sci. 85(Suppl. 1):98. (Abstr.)

Bolinger, D. J., J. L. Albright, J. Morrow-Tesch, S. J. Kenyon, and M. D. Cunningham. 1997. The effects of restraint using selflocking stanchions on dairy cows in relation to behavior, feed intake, physiological parameters, health, and milk yield. J. Dairy Sci. 80:2411-2417.

Britt, J. H., N. M. Cox, and J. S. Stevenson. 1981. Advances in reproduction in dairy cattle. J. Dairy Sci. 64:1378-1402.

Burke, J. M., R. L. de La Sota, C. A. Risco, C. R. Staples, E. J. P. Schmitt, and W. W. Thatcher. 1996. Evaluation of timed insemination using a gonadotropin-releasing hormone agonist in lactating dairy cows. J. Dairy Sci. 79:1385-1393.

Cartmill, J. A., S. Z. El-Zarkouny, B. A. Hensley, G. C. Lamb, and J. S. Stevenson. 2001. Stage of cycle, incidence and timing of ovulation, and pregnancy rates in dairy cattle after three timed breeding protocols. J. Dairy Sci. 84:1051-1059.

Chenault, J. R., D. D. Kratzer, R. A. Rzepkowski, and M. C. Goodwin. 1990. LH and FSH response of Holstein heifers to fertirelin acetate, gonadorelin and buserelin. Theriogenology 34:81-98. 
Chenault, J. R., W. W. Thatcher, P. S. Kalra, R. M. Abrams, and C. J. Wilcox. 1975. Transitory changes in plasma progestins, estradiol, and luteinizing hormone approaching ovulation in the bovine. J. Dairy Sci. 58:709-717.

Chenault, J. R., W. W. Thatcher, P. S. Kalra, R. M. Abrams, and C. J. Wilcox. 1976. Plasma progestins, estradiol, and luteinizing hormone following prostaglandin F2 alpha injection. J. Dairy Sci. 59:1342-1346

Dailey, R. A., J. C. Price, K. R. Simmons, E. M. Meisterling, P. A. Quinn, and S. P. Washburn. 1986. Synchronization of estrus in dairy cows with prostaglandin F2 alpha and estradiol benzoate. J. Dairy Sci. 69:1110-1114.

Dobson, H., J. E. Tebble, R. F. Smith, and W. R. Ward. 2001. Is stress really all that important? Theriogenology 55:65-73.

Dransfield, M. B., R. L. Nebel, R. E. Pearson, and L. D. Warnick. 1998. Timing of insemination for dairy cows identified in estrus by a radiotelemetric estrus detection system. J. Dairy Sci. 81:1874-1882

El-Zarkouny, S. Z., J. A. Cartmill, B. A. Hensley, and J. S. Stevenson. 2004. Presynchronization of estrous cycles before Ovsynch and progesterone in dairy cows: Ovulation, pregnancy rates, and embryo survival. J. Dairy Sci. 87:1024-1037.

El-Zarkouny, S. Z., and J. S. Stevenson. 2004. Resynchronization of estrus with progesterone or progesterone plus estrogen in lactating dairy cows of unknown pregnancy status. J. Dairy Sci. 87:3306-3321.

Hansel, W., and E. M. Convey. 1983. Physiology of the estrous cycle. J. Anim. Sci. 57:404-423.

Lefebvre, D. M., and E. Block. 1992. Effect of recombinant bovine somatotropin on estradiol-induced estrous behavior in ovariectomized heifers. J. Dairy Sci. 75:1461-1464.

Lopes, F. L., D. R. Arnold, J. Williams, S. M. Pancarci, M-J. Thatcher, M. Drost, and W. W. Thatcher. 2000. Use of estradiol cypionate for timed insemination. J. Dairy Sci. 83(Suppl. 1):214. (Abstr.)

Lucy, M. C., and J. S. Stevenson. 1986. Gonadotropin-releasing hormone at estrus: Luteinizing hormone, estradiol, and progesterone during the periestrual and postinsemination periods in dairy cattle. Biol. Reprod. 35:300-311.

Moberg, G. P., J. G. Watson, D. P. Stoebel, and R. Cook. 1981. Effect of cortisol and dexamethasone on the oestrogen-induced release of luteinizing hormone in the anoestrous ewe. J. Endocrinol. $90: 221-225$.

Moreira, F., C. Orlandi, C. A. Risco, R. Mattos, F. Lopes, and W. W. Thatcher. 2001. Effects of presynchronization and bovine somatotropin on pregnancy rates to a timed artificial insemination protocol in lactating dairy cows. J. Dairy Sci. 84:1646-1659.

National Research Council. 1989. Nutrient Requirements of Dairy Cattle. 5th rev. ed. Natl. Acad. Sci., Washington, DC.

Pancarci, S. M., E. R. Jordan, C. A. Risco, M. J. Schouten, F. L. Lopes, F. Moreira, and W. W. Thatcher. 2002. Use of estradiol cypionate in a presynchronized timed artificial insemination program for lactating dairy cattle. J. Dairy Sci. 85:122-131.

Pursley, J. R., M. O. Mee, and M. C. Wiltbank. 1995. Synchronization of ovulation in dairy cows using $\mathrm{PGF}_{2 \alpha}$ and $\mathrm{GnRH}$. Theriogenology 44:915-923.
Pursley, J. R., M. C. Wiltbank, J. S. Stevenson, J. S. Ottobre, H. A. Garverick, and L. L. Anderson. 1997. Pregnancy rates per artificial insemination for cows and heifers inseminated at a synchronized ovulation or synchronized estrus. J. Dairy Sci. 80:295-300.

Richardson, A. M., B. A. Hensley, T. J. Marple, S. K. Johnson, and J. S. Stevenson. 2002. Characteristics of estrus before and after first insemination and fertility of heifers after synchronized estrus using GnRH, $\mathrm{PGF}_{2 \alpha}$, and progesterone. J. Anim. Sci. 80:27922800 .

Short, R. E., R. D. Randel, R. B. Staigmiller, and R. A. Bellows. 1979. Factors affecting estrogen-induced $\mathrm{LH}$ release in the cow. Biol. Reprod. 21:683-689.

Skaggs, C. L., B. V. Able, and J. S. Stevenson. 1986. Pulsatile or continuous infusion of luteinizing hormone-releasing hormone concentrations in prepubertal beef heifers. J. Anim. Sci. 65:1034-1048

Stevenson, J. S., S. K. Johnson, M. A. Medina-Britos, A. M. Richardson, and G. C. Lamb. 2003. Resynchronization of estrus in cattle of unknown pregnancy status using estrogen, progesterone, or both. J. Anim. Sci. 81:1682-1692.

Stevenson, J. S., Y. Kobayashi, M. P. Shipka, and K. C. Rauchholz. 1996. Altering conception of dairy cattle by gonadotropin-releasing hormone preceding luteolysis induced by prostaglandin $\mathrm{F}_{2 \alpha}$. J. Dairy Sci. 79:402-410.

Stevenson, J. S., Y. Kobayashi, and K. E. Thompson. 1999. Reproductive performance of dairy cows in various programmed breeding systems including Ovsynch and combinations of gonadotropinreleasing hormone and prostaglandin $\mathrm{F}_{2 \alpha}$. J. Dairy Sci. 82:506515.

Stevenson, J. S., M. F. Spire, and J. H. Britt. 1983. Influence of the ovary on estradiol-induced luteinizing hormone release in postpartum milked and suckled Holstein cows. J. Anim. Sci. $57: 692-698$.

Stoebel, D. P., and G. P. Moberg. 1982. Repeated acute stress during the follicular phase and luteinizing hormone surge of dairy heifers. J. Dairy Sci. 65:92-96.

Stumpf, T. T., M. W. Wolfe, M. L. Day, J. A. Stotts, P. L. Wolfe, R. J. Kittok, and J. E. Kinder. 1989. Effect of 17-beta-estradiol on the preovulatory surge of LH in the bovine female. Theriogenology 36:201-207.

Vailes, L. D., S. P. Washburn, and J. H. Britt. 1992. Effects of various steroid milieus or physiological states on sexual behavior of Holstein cows. J. Anim. Sci. 70:2094-2103.

Vasconcelos, J. L. M., R. W. Silcox, G. J. Rosa, J. R. Pursley, and M. C. Wiltbank. 1999. Synchronization rate, size of the ovulatory follicle, and pregnancy rate after synchronization of ovulation beginning on different days of the estrous cycle in lactating dairy cows. Theriogenology 52:1067-1078.

Vynckier, L., M. Debackere, A. DeKruif, and M. Coryn. 1990. Plasma estradiol- $17 \beta$ concentrations in the cow during induced estrus and after injection of estradiol-17 $\beta$ benzoate and estradiol-17 $\beta$ cypionate-a preliminary study. J. Vet. Pharmacol. Therapy 13:36-42. 